\title{
KAJIAN NILAI DIDAKTIK DALAM SASTRA BALI KLASIK: MENGGALI KEUNGGULAN KEARIFAN LOKAL SEBAGAI PENDIDIKAN MORAL GENERASI MUDA SAAT INI
}

\author{
I Nengah Duija \\ Institut Hindu Dharma Negeri Denpasar \\ nengahduija@yahoo.com
}

\begin{abstract}
ABSTRAK
Pengkajian sastra klasik sudah saatnya diperlukan sebagai sebuah pendekatan budaya dalam mengantisipasi tergerusnya tata nilai generasi muda sekarang ini. Asumsi mendasar yang patut menjadi urgensi pengkajian itu adalah, bahwa sastra Bali Klasik sesungguhnya sebuah cermin diri dari masyarakat Bali itu sendiri (masuluh ring sastra=bercermin pada sastra/pengetahuan). Oleh karena itu, tentu sastra mengandung tata nilai yang adhi luhung (nora na mitra mangluwihana waraguna maruhur=tidak ada sahabat yang melebihi keagungan ilmu pengetahuan yang tinggi). Penelitian ini bermaksud untuk mengungkapkan nilai-nilai didaktik yang terkandung dalam kesusastraan Bali klasik dan relevansi nilai-nilai itu dalam mengembangkan pendidikan moral generasi muda saat ini.

Pengkajian ranah ini belum banyak diteliti oleh putra daerah maupun peneliti luar daerah, akan tetapi penelitian kearah itu telah dilakukan oleh para pakar sastra Bali. Penelitian ini menggunakan metode sosiologi sastra dengan menerapkan teori reseptif, dengan langkah kajian sebagai berikut :Teknik pengumpulan datanya diawali dengan pengumpulan teks yang dijadikan sumber kajian yaitu : Geguritan Putra Sasana, Geguritan Basur, Cerita Tantri, dan Cerita Bhagawan Dhomya. Analsis datanya secara deskriptif kualitatifdengan bertumpu pada teks sumber sebagai bahan analisis.Analisis data ini diawali dengan kajian nilai-nilai didaktik yang terkandung dalam cerita klasik Bali dan relevansinya bagi pendidikan moralgenerasi muda saat ini.

Hasil analisis ternyata banyak sekali terkandung nilai-nilai didaktik dalam keempat sumber naskah di atas, yang dapat ditransformasikan untuk sistem pendidikan dewasa ini, antara lain:konsep pendidikan seumur hidup, pendidikan akal, tanggung jawab guru dan murid, ini diteruskan kepada anak didik, yang sesungguhnya dapat dijadikan materi pengayaan pengetahuan kearifan lokal yang mampu memberikan rambu-rambu moralitas yang baik di kalangan generasi muda saat ini, yang lebih cenderung hanya menggunakan paradigma pendidikan Barat dibandingkan membangun kepribadian berdasarkan tata nilai yang telah diwariskan oleh nenek moyang dalam bentuk sastra-sastra klasik. Untuk itu perlu diadakan pembinaan oleh intansi terkait untuk lebih mengarahkan diri pada peranan ilmu humaniora dalam rangka meningkatkan kualitas manusia dengan cara pendidikan budi pekerti dengan menggali kearifan local sebagai keunggulan budaya di mana masyarakat itu hidup dan berkembang.

Kata kunci: teks dedaktik, sastra Bali klasik, kearifan local
\end{abstract}




\section{ABSTRACT}

The classical literary review is necessary as a cultural approach in anticipating the degradation of the values of today's young generation. The fundamental assumption that should be urgency of the study is that the classical Balinese literature is actually a self-reflection of the Balinese society itself (masuluh ring sastra $=$ reflecting on the literature/knowledge). Therefore, of course the literature contains worthy value (nora na mitra mangluwihana waraguna maruhur = no friend exceed the greatness of science). The study intends to reveal the didactic values contained in classical Balinese literature and the relevance of those values in developing the moral education of the young generation today.

The study of this domain has not been widely studied by the local researcher and researchers outside the region, but research in that direction has been done by experts of Balinese literature. The present study used sociology method of literature by applying receptive theory, with the following study steps: Data collection techniques began by collecting the texts that were used as the sources of the study, such as: Geguritan Putra Sasana, Geguritan Basur, Tantri story, and Bhagawan Dhomya story. Data analysis used descriptive qualitative relied on source texts as the material of analysis. Data analysis began with the study of didactic values contained in Balinese classical story and the relevance to the moral education of young generation today.

Analysis result shows that many didactic values contained in the four text sources above, which can be transformed to the education system today, namely: the concept of education for life, the intellectual education, the responsibilities of teachers and students, is passed on to the students, which can actually be the material of enrichment of knowledge of local wisdom that is able to give a good sign of good morality among young people today, who are more likely to only use Western educational paradigm than building a personality based on the values that have been inherited by the ancestors in the form of classical literatures. Therefore, it needs to be guided by the relevant institution to be more directed to the role of the humanities sciences in order to improve the quality of human by way of moral education by exploring local wisdom as a cultural excellence in which the community lives and thrives.

Key words: Didactic Text, Balinese Classical Literature, Local Wisdom

\section{PENDAHULUAN}

Pendidikan merupakan bentuk kebutuhan yang berlangsung sepanjang hidup manusia (long life education). Dalam arti luas pendidikan didefinisikan sebagai usaha sadar untuk mewujudkan dan mengembangkan keperibadian dan potensi manusia, baik oleh dirinya sendiri maupun dengan bantuan orang lain (memberikan keteladanan bimbingan, pengagjaran, dan pelatihan).yang berlangsung sepanjang hayat. Pendidikan Menurut UU No.20/2003 tentang sistem pendidikan nasional:Pasal 1 (ayat 1) berbunyi: Pendidikan adalah usaha sadar dan terencana untuk mewujudkan suasana belajar dan proses pembelajaran agar peserta didik secara aktif mengembangkan potensi dirinya untuk memiliki spiritual keagamaan, pengendalian diri, kepribadian, kecerdasan, akhlak 
mulia, serta keterampilan yang diperlukan dirinya, masyarakat, bangsa dan negara.

Menyimak ketentuan tersebut, maka lewat karya sastra baik secara langsung maupun tidak langsung, sesungguhnya pengarang selaku bagian dari keluarga atau masyarakat juga mempunyai tanggung jawab sosial terhadap pendidikan. Sastra atau karya sastra yang lahir dan tumbuh berkembang di tengah kehidupan masyarakat, merupakan medis yang tak dapat dianggap kecil artinya bagi proses pendidikan manusia. Sastra sebagai hasil budaya bangsa merupakan salah satu produk yang banyak merekam gagasan-gagasan, pemikiran-pemikiran, pandangan hidup, tata nilai, pendidikan moral dan keindahan. Hal ini sesuai dengan apa yang dinyatakan Suyitno (1986:3) pelahiran sastra bersumber dari kehidupan yang bertata nilai yang pada gilirannya nanti sastra juga akan memberikan sumbangan bagi terbentuknya tata nilai kehidupan. Dengan demikian sebuah karya sastra penting untuk dibaca, ditafsirkan, dipertimbangkan dan dikaji secara ilmiah untuk disumbangkan dan dimanfaatkan bagi ilmu pengetahuan dan pembangunan bangsa Indonesia dalam arti yang seluas-luasnya.

Dalam upaya pemanfaatan sastra sebagai salah satu media pendidikan, Plato mengemukakan bahwa petapa pentingnya sastra bagi pendidikan anak (Dalam Damono,1978:15). lebih lanjut dikatakan puisi merupakan salah satu genre (jenis) sastra pada jaman itu, memegang peranan yang cukup penting dalam pendidikan. Akan tetapi berbagai hal harus tetap diperhatikan, bahwa cerita-cerita yang beredar di masyarakat harus disensor terlebih dahulu sebelum disampaikan kepada anak-anak. Anak didik sebaiknya hanya menerima cerita yang tidak mengandung hal-hal yang dimungkinkan bisa menyesatkan, melainkan yang lebih penting harus memberikan tuntunan dan bimbingan bagi keluhuran budi, kejatmikan dan kearifan kepribadian anak (Damono,1979:17).

Sehubungan dengan dasar penafsiran di atas, maka tulisan ini akan mencoba dan berusaha mengkaji beberapa teks sastra Bali klasik yang merupakan bagian dari kesusastraan Bali Tradisional (purwa). kajian ini akan menyoroti beberapa sastra Bali klasik, yaitu Geguritan Putra Sasana, Geguritan Basur, Cerita Tantri, dan Posya Carita Bhagawan Dhomya.Pokok permasalahan yang akan disoroti dalam tulisan ini Nilai-nilai pendidikan apa saja dapat disimak dalam Sastra Bali Klasik dan relevansi nilai-nilai pendidikan yang termuat dalam Sastra Bali Klasik dalam upaya pengembangan moralitas generasi muda saat ini.

Tujuan penelitian ini adalah secara teoretis dimaksudkan adalah tujuan untuk menunjukkan bagaimana penggunaan kata/kalimat atau bahasa secara umum dalam karya sastra Bali Klasik.Hal ini berpijak dari pemikiran yang dikemukakan Riffaterre(1971:1) bhawa puisi mengekspresikan konsep-konsep secara tidak langsung. Apa-apa yang dinyatakan dengan kata-kata dalam puisi mempunyai maksud yang lain, sehingga tidak jarang terjadi ketidaklangsungan semantik. Karena itu, diperlukan pemahaman yang cermat dan teliti terhadap bahasa dalam karya Sastra.Demikian juga halnya dengan pemahaman terhadap karya Sastra Bali Klasik yang merupakan salah satu bagian dari kesusastraan Bali. Pembedahan yang mahir terhadap aspek bahasa/kebahasaan (semantik) dari teksteks di atas akan dianalisis secara teoretis. Secara praktis apa yang dikatakan Teeuw (1984:8), bahwa masalah penelitian jenis sastra sebagaimana pokoknya 
diambil dari teori yang dikembangkan dalam "poetika" tulisan Aristoteles, maka sifat dulce (nikmat=objeknya perasaan/emosi) dan utile (bermanfaat=tata nilai kehidupan). Sebagai fungsi atau tujuan karya sastra yang pertama kali dipaparkan oleh Horatius bagi banyak pembaca sastra adalah tetap merupakan tolak ukur sastra. Maksudnya anggota masyarakat dalam memberikan tanggapan dan penafsiran terhadap pikiran-pikiran yang dituangkan oleh pengarang dalam karya sastranya mutlak menuntut perlengkapan konseptual akan sistem tanda dalam bahasa sastra tersebut. Menurut Wellek \& Werren (dalam Ghazali at.al. 1978:127), bahwa dalam proses inilah makna muatan (actual meaning), yaitu makna yang terdapat dalam karya itu dan interpretasinya dapat diteruskan. Dengan demikian komunikasi apa yang terbentuk dalam masyarakat pembaca dengan karya sastra yang dibaca dapat bermanfaat secara praktis menjadi dikenal dan dipahami nilai-nilai apa yang sedang diketengahi.

Mengingat data atau bahan penelitian ini berupa teks-teks Geguritan dan Cerita Prosa, maka untuk mengungkapkan gejala-gejala pikiran pengarang, nilainilai yang dikandungnya, akan diterapkan teori strukturalisme-semiotik dan sosilogi sastra. Kedua teori tersebut akan diterapkan sebagai satu kesatuan untuk menghindari pembicaraan yang tumpang tindih.

Teori strukturalisme yang dipergunakan adalah mengacu pada pendapat Teeuw (1984:61) yang mengemukakan bahwa pendekatan sastra penelaahan struktur merupakan salah satu tugas prioritas, sedangkan semiotik adalah lanjutan analisis struktural. Pembaca bertugas memberi makna pada sebuah karya sastra haruslah mulai dengan meaning unsur-unsur, yaitu kata-kata yang menurut kemampuan bahasanya yang berdasarkan fungsi bahasa sebagai alat komunikasi tentang gejala luar (mimetic function). Selanjutnya pembaca haruslah meningkatkan pengamatan pada tataran semiotik.Dalam tataran semiotik kode karya sastra itu dibongkar (decoding) secara struktural atas dasarsignifikannya.Penyimpangan dari kode bahasa atau dari makna biasa secara mimetik mendapatkan makna semiotik. Abrams (dalam Teeuw,1984:50) mengatakan bahwa dalam menghadapi karya sastra secara ilmiah pada prinsipnya dapat dimanfaatkan empat pendekatan teoretik yang secara langsung dapat dijabarkan dari situasi karya sastra. Keempat pendekatan tersebut masing-masing menonjolkan " (a) peranan penulis sebagai pencipta, (b) peranan pembaca sebagai penyambut, (c) aspek referensial, acuan karya sastra yang dihubungkan dengan dunia nyata, dan (d) karya sastra sebagai sesuatu yang otonom. Penelitian ini dalam analisis lebih menonjolkan pada teori (b) dan (c). Hal ini dikaitkan dengan tujuan dan hasil yang hendak dicapai. Mengingat sastra bukan jatuh dari langit, melainkan diciptakan oleh pengarang yang tentunya tidak dapat lepas atau melepaskan diri dari masyarakat, maka penelitian ini juga melibatkan sosiologi sastra, pendekatan terhadap sastra yang mempertimbangkan segi kemasyarakatan (Damono,1978: 2). Pendekatan sosiologi sastra bertumpu dari paham pandangan bahwa lewat karya sastra pengarang mengucapkan kehidupan masyarakat yang direkamnya melalui persepsi dan penalaran intuisinya.Dalam pemahaman terhadap tema, amanat, dan nilai-nilai pendidikan yang terkadung dalam karya sastra hendaknya dilihat dari struktur yang integral. 
Kesusatraan Bali pada dasarnya dibagi atas Sastra Bali Tradisional atau Sastra Bali Purwa dan Sastra Bali Modern atau Sastra Bali Anyar. Kesusastraan Bali Tradisional oleh Robson (1978:9) diistilahkan sebagai Sastra (Bali) klasik, yaitu karya sastra yang berkenaan dengan masalah waktu atau sastra-sastra yang berasal dari jaman pramodern sebelum adanya pengaruh eropa secara intensif. Lebih lanjut Robson mengatakan, bahwa dalam karya-karya sastra tersebut ada terkandung sesuatu yang amat penting dan berharga yaitu sebagian warisan rohani budaya budaya bangsa Indonesia dan merupakan perbendaharaan pikiran dan citacita nenek moyang (ibid,1978:9). Oleh karena merupakan cita-cita dan hasil pemikiran yang unggul para nenek moyang, maka penting bagi kita untuk dikaji. Berdasarkan penjelasan itu, maka peranan sastra (Bali) sangat penting dalam kehidupan masyarakat, seperti yang dikatakan oleh Saini KM(1989: 15-16), bahwa ada tiga kedudukan sastra dalam kehidupan yakni (1) sebagai perekat (intensidikator); dalam hal ini sastra memekatkan pengalaman hidup manusia, disaring, dijernihkan, diambil inti sarinya sehingga pembaca dapat mengambil pesan yang disampaikan pengarang secara tepat; (2). Sastra sebagai penentangan, dalam hal ini sastra dianggap kontradiksi terhadap kehidupan oleh karena sastra tampil sebagai protes sosial; (3) Sastra untuk memperolok-olok, hal ini dimaksudkan menggugah kemampuan manusia untuk merenungkan kehidupan dengan lebih luas dan mendalam. The Liang Gie (1983: 73) menyatakan seni (sastra) juga menyebabkan orang sadar akan realita subjektif, pengalaman intern dari perasaannya. Ini berarti seorang pembaca sastra, apa yang mereka nikmati dalam bacaan itu ia akan sadar akan perbuatannya sendiri dari tokoh itu, minimal ia akan sadar atas perbuatannya sendiri dari tokoh atau kejadian yang terjadi dalam sastra tersebut. Oleh karena itu, minimal sastra itu (klasik) dapat dipakai media untuk menumbuhkan moral atau kepribadian sang pencinta sastra. Melaui cerita klasik akan tersentuh hati nurani si anak untuk cendrung melakukan perbuatan yang baik. Seperti apa yang dikatakan oleh Gribstain dikutip Djoko Damono (1978:5). Sastra yang dapat bertahan lama pada hakikatnya merupakan moral baik dalam hubungan dengan seorang maupun dengan hubungan dalam kebudayaan sumbernya. Moral dimaksud dalam hal ini adalah pengertian moral dalam arti yang luas, bahwa sastra terlibat dalam berbagai kehidupan dan memberi tanggapan evaluatif. Sebuah cipta sastra pada pokoknya memiliki nilainilai estetika, nilai-nilai moral, nilai-nilai yang bersifat konsepsional (Esten, 1978: 7). Demikian pula apa yang dikatakan oleh Yudibrata (1982:10) dalam sebuah cipta sastra ada empat nilai pokok, yaitu: nilai agama, nilai logika, nilai etika, dan nilai estetika.

Kembali pada sastra klasik, yang dalam hal ini adalah sastra Bali Kalsik yang berbentuk puisi (geguritan) dan prosa (gancaran). Geguritan adalah suatu karangan yang dibentuk oleh pupuh atau pupuh-pupuh dan pupuh-pupuh itu diikat oleh beberapa syarat (Agastia,1980:17). Lebih lanjut dikatakan syarat-syarat pupuh itu disebut padalingsa, yaitu banyaknya baris dalam tiap bait (pada), banyaknya suku kata dalam tiap-tiap bait (carik), dan bunyi akhir tiap-tiap baris menyebabkan pupuhitu harus dilagukan.

Di dalam geguritan dan satua (cerita) banyak sekali terkandung ajaran atau pesan-pesan yang bersifat didaktik terutama dalam pembinaan dan 
pendidikan moral anak.Dalam sastra geguritan umumnya telah terdapat nilai-nilai moral yang universal (Agastia, 1980: 24). Demikian pula cerita-cerita Bali klasik kaya akan muatan nilai-nilai didaktik yang dapat ditransformasikan menurut perkembangan hidup manusia, nilai didaktik yang terkandung di dalamnya lebih mengacu pada pembinaan dan pembentukan moral anak-anak, dalam artian sastra tidak bersifat doktrin, tetapi lebih banyak mengajarkan sesuatu dengan cara meniru. Nilai tersebut menembushati nuraninya, bukan fisik dari generasi muda. Nilai-nilai pendidikan yang terdapat dalam sastra Bali Klasik (baca: satua=dongeng) adalah unsur pendidikan sesuai dengan moral pendidikan Nasional (Bagus, 1968:4). Menurut Bagus nilai-nilai rohani yang dimaksud adalah : (a) bahwa dalam dongeng itu tampak adanya kepercayaan kepada zat yang menentukan nasib manusia, (b) dalam dongeng terdapat motif dimana kebajikan-kebajikan, perbuatan-perbuatan yang baik mendapatkan pahala yang baik dan sebaliknya perbuatan-perbuatan yang buruk berpahala bruk pula, (c) bahwa dalam dongeng tersebut terdapat ajaran-ajaran yang mengandung kewajiban-kewajiban baik kewajiban si anak kepeada leluhurnya maupun kewajiban-kewajiban sosial terhadap sesamenya bahkan untuk sekalian makhluk, (d) dalam dongeng itu juga terdapat bahwa kelalaian yang ada pada tangan yang berkuasa akhirnya akan runtuh walaupun kekuatan itu datangnya daru irang miskin sekalipun.

Oleh karena dalam sastra klasik (dongeng) kaya akan nilai pendidikan, maka dipandang seperti apa yang dikatakan oleh Ki Hajar Dewantara (dalam Bagus, 1968: 7). Ki Hajar Dewantara mengatakan:

"Pengajaran bahasa yang baik harus berujud sinthetis dengan mengggabungkan pelajaran bahasa dengan pelajaran cerita dan lagu, agar dapatlah kita maklumkan anak-anak dalam ilmu dan kecakapan bahasa serta memperdalam dan meluhurkan pengajaran bahasa itu. Dengan metodik yang demikian pengajaran bahasa bukan lagi semata-mata bersifat ilmu bahasa, akan tetapi menjadi kulturil, dan terbukalah karenanya lapangan untuk si pengajar dan guru, akan melakukan kewajiban paidogogis yaitu "Tut Wuri Handayani" dalam perkaramoril. Tak boleh dilupakan bahwa metode sinthetis itu lebih menyenangkan anak-anak oleh karena lebih hidup dan "dipraktekkan" lagi pula dialami oleh jiwanya anak.Pendidikan adalah serangkaian komunikasi yang bertujuan antar manusia dewasa dengan perkembangan anak seutuhnya, dalam arti supaya dapat mengembangkan potensinya semaksimal mungkin, agar menjadi manusia yangbertanggung jawab.Potensi disini ialah potensi, emosi, sosial, sikap moral, pengetahuan dan keterampilan (Zahara, Idris, 1981: 10-11).

\section{METODE PENELITIAN}

Penelitian ini menggunakan paradigma kualitatif mengingat analisis yang dilakukan menggunakan sumber pokok teks sastra. Ketajaman analisa lebih diutamakan menggunakan analisis interpretatif. Data diperoleh melalui penelusuran teks Sastra Bali Klasik yang akan dikaji nilai didaktisnya, dengan mengabaikan pencermatan yang bersifat filologis. Dengan kecermatan membaca teks yang akan dipilih secara acak berdasarkan pengamatan maka, didapatkan 
bahwa teks Sastra Klasik yang dijadikan sumber kajian, yaitu : Geguritan Putra Sasana, Geguritan Basur, Cerita Tantri, dan Posya Bhagawan Dhomya. Teks ini hasil penelusuran dari koleksi perpustakaan Lontar Fakultas Sastra Unud, Perpustakaan Gedong kirtya dan beberapa perpustakaan perorangan.

Pada tahap analisis data terhadap teks-teks yang dijadikan sumber data, dipergunakan teknik terjemahan, yaitu berusaha memindahkan pesan dan kesan teks (makna teks) asli semaksimal mungkin, dengan menjaga kesejajaran dan kelancaran bahasa sasaran, dengan demikian nilai-nilai yang terutama berkaitan dengan ide-ide pendidikan yang terkandung akan dapat disimak dengan jelas. Tentu dalam hal ini digunakan juga metode analitis sintetis atas dasar kerja strukturalisme semiotik dnegan tetap melihat kaitan dengan masyarakat pendukungnya (reseptif).Dalam pengungkapan nilai pendidikan (didaktik) yang hendak dicapai dalam penelitian Sastra Klasik ini dilandasi dengan pola berpikir deduktif-induktif sebagai usaha untuk mengekplisitkan ke dalam noma-norma pendidikan moral generasi muda saat ini.

\section{HASIL PENELITIAN DAN PEMBAHASAN}

Gagasan-gagasan tentang pendidikan dalam karya sastra Bali Klasik yang masih relevan untuk diteruskan dewasa ini.Akan tetapi dapat disadari dalam arus modernisasi sekarang ini gagasan-gagasan tersebut telah mengalami pembaharuan bentuk pengujian sehingga dirasakan tidak ada kesinambunagn ide antara yang lama dengan yang modern. Berdasarkan uraian di atas dapat disadari bahwa sejauh mana peran serta lembaga pendidikan dalam mewujudkan kesinambunagn nilai-nilai tradisional dan niali-niali modern yang bersifat dialektika dengan prinsip keberlanjutan dalam perubahan. Tidak selamanya yang tradisional itu kolot, demikian pula sebaliknya tidak semuanya modern baik. Untuk itu perlu digali kembali kristal-kristal yang terpendam dalam sastra klasik yang telah termakan usia, namun justru memiliki konsepsi yang bisa diterapkan untuk tata nilai kehidupan dewasa ini.

\section{Konsep Putra Sesana}

Geguritan Putra Sesana pada garis besarnya merupakan ajaran etika tingkah laku seorang putra dan juga menyinggung tentang kewajiban orang tua terhadap anak.Putra artinya putra atau anak.Sesana artinya kewajiban yang harus dilakukan.Geguritanini disalin dari lontar ke dalam bentuk buku cetakan oleh Anak Agung Made Regeg (alm), selesai disalin pada tanggal 1 bulan Maret 1955. Dalam Geguritan Putra Sasana ini terkandung hakikat pemeliharaan anak-anak baik secara fisik maupun secara rohani yang dituangkan dalam bentuk pupuh. Untuk itu nilai-nilai didaktik yang terkandung dalam sastra Bali Klasik khususnya Geguritan Putra Sasana ini yang dapat diteruskan dalam sistem pendidikan karakter generasi mudadewasa ini antara lain sebagai berikut.

1. Adanya konsep pemeliharaan dan perhatian terhadap anak-anak sebagai penerus keturunan dan penerus bangsa. Konsep ini sampai sekarang masih dipegang teguh dan dilaksanakan bukan sekedar perhatian, tetapi lebih dari itu, salah satu diantaranya adalah dengan mendidik anak-anak baik melalui jalur informal, formal dan non formal. 
2. Adanya ide tentang kewajiban si anak kepada leluhurnya, pendidikan ini dapat ditransformasikan kedalam sistem pendidikan dewasa ini, yaitu pendidikan budi pekerti, melalui pendidikan ini diharapkan sianak mampu menanamkan dalam dirinya rasa tat twam asi, rasa tenggang rasa, antar sesama, keluarga, masyarakat dan Negara.

3. Konsep menasehati si anak, menasehati anak-anak tidak perlu dengan kekerasan, sebab semakin sering dikerasi si anak akan semakin tidak menghiraukan nasehat yang disampaikan.Perlu diperhatikan apa yang diajurkan atau yang terdapat dalam Geguritan Putra Sasana itu, supaya mendidik anak itu tidak dengan jalan kekerasan, tetapi dengan cara yang lebih halus dan penuh pengertian, sehingga mereka menjadi senang dengan perlakuan orang tua kepada dia sebagai seorang anak. Mungkin saja salah satu cara untuk itu adalah memberikan si anak itu cerita-cerita yang mereka sukai.

4. Disamping tersebut di atas, maka peranan lingkungan dan pergaulan ikut juga menentukan watak si anak, menurut Geguritan ini dalam suatu pergaulan harus selektif, salah bergaul bisa menyebabkan penyesalan dalam diri. Di sini peranan lembaga pendidikan mulai dari bawah hingga ke atas, sangat menentukan tumbuh-kembangnya sianak dan generasi muda penerus bangsa.

5. Konsep memberikan dan menerima, hal ini perlu diajarkan kepada anak didik, supaya di dalam memberikan sesuatu kepada teman atau orang lain selalu berdasarkan pada hati yang tulus ikhlas. Demikian pula dalam menerima sesuatu dari orang lain, jangan pemberian seseorang itu dilupakan walaupun itu jumlahnya sedikit.

Konsepsi-konsepsi tersebut di atas dapat diteruskan kepada anak-anak Indonesia dewasa ini dalam pendidikan budi pekerti yang secara terintegrasi dapat diberikan pada pelajaan agama, pendidikan moral Pancasila, ataupun dapat dituangkan sebagai selingan dalam proses belajar mengajar, namun permasalahannya mampukah guru itu menyampaikannya tentang nilai-nilai yang terkandung dalam sastra itu kepada anak didiknya dengan metode yang tepat sehingga tersentuh hati nuraninya untuk melaksanakannya. Untuk itu memerlukan cara pandang yang sama di semua komponen pendidikan itu sendiri.

\section{Gaguritan Basur}

Masalah kesinambungan ini tentang nilai-niali didaktik yang dibicarakan memang sepintas lalu sulit diberi batas yang jelas, namun beberapa konsep dari Geguritan Basur ini masih tercermin pada sistem pendidikan anak dewasa ini hanya saja telah ditransformasikan atau diwujudkan dalam bentuk-bentuk lain sesuai dengan kemajuan jaman. Hla ini dapat dilihat dalam beberapa hal antara lain :

1. Pendidikan seumur hidup, konsep ini dalam Geguritan Basur telah ada, bahkan sampai sekarang realisasinya batas usia dalam artian, mulai taman kanak-kanak sampai perguruan tinggi tidak ada istilah terlambat.

2. Konsep menabung, dalam Geguritan Basur disajikan pelajaran tentang hidup irit, dan ini perlu ditanamkan pada diri anak-anak semasa sekolah dasar, baik itu diajarkan menyimpan uang dalam bentuk celengan. 
Pada prinsipnya terdapat kesinambungan antara konsep pendidikan dalam Geguritan Basur dengan sistem pendidikan anak jaman ini walaupun secara kuantitas sangat sedikit, akan tetapi sifatnya yang sangat prinsip itu, perlu digali kembali sebagai sebuah kearifan local atau local genius.

\section{Cerita Tantri}

Rajendra Mishra (1988:48) menyebutkan Cerita Tantri ini masing-masing terdiri atas nasehat dan pengajaran (didaktik).Cerita Tantri pada prinsipnya mengandung ajaran didaktik, yaitu bagaimana caranya menggunakan akal dalam menghadapi rintangan-rintangan hidup.Dalam sistem pendidikan anak dewasa ini masih dapat dilihat pada pendidikan sekolah dasar, si anak diberikan semacam permainan itu dapat disusun menjadi sesuatu yang utuh, si anak disuruh menyusun kembali sesuai dengan bentuk semula. Di dini si anak mulai menggunakan akalnya bukan hanya sekedar meniru dan menjiplak apa yang sudah jadi, pada sistem ini si anak diberikan kesempatan untuk menggunakan logika pikirannya, semakin sering latihan akal seperti ini, maka semakin tanggap anak-anak dengan situasi dan memiliki kekuatan mental dan logika yang kuat untuk menghadapi goncangan hidup saat ini.

\section{Posya Carita Bhagawan Domya}

Cerita ini memang bercerita tentang sistem pendidikan, yaitu sistem pendidikan asrama, murid-murid tinggal bersama gurunya, jika diperhatikan cerita ini yang merupakan petikan dari epos besar Mahabharata terutama bagian parwa yang pertama, yaitu Adiparwa. Gagasan tentang pendidikan (pasraman) atau asrama (boarding school) ini memang belakangan ini tidak ditemukan lagi, namun ada suatu yang perlu diperhatikan dalam posya carita ini yaitu, adanya sistem seleksi sebelum mulai belajar, yang sampai saat ini masih berlaku terutama tanggung jawab moral yang dipegang oleh seorang pendidik untuk menjadikan anak-anak mampu menjadi dewasa jasmani dan rohani.

\section{Analisis Nilai-nilai Kearifan Lokal dalam Sastra Bali Klasik}

Aspek-aspek penddikan dalam Geguritan Putra Sasana, seperti yang telah uraikandi atasadalah sebagai berikut :

- Tangung jawab orang tua dalam proses pendidikan anak, seperti pada kutipan berikut :

Wenten ring sastra inucap, iwang dados anak lingsir, yang tan okane sakolahang, mangde uning ring pamargi, bekel anake numadi, kaungguhang ala ayu, jele melah suka duka, punika sami kapanggih, pacang temu, ring sekala niskala (PS: Puh. Sinom, b.1)

Terjemahannya :

Dalam sastra ada disebutkan, salahlah jadi orang tua bila tidak menyekolahkan anak, supaya pintar dan tahu jalan hidup, sebagai bekal orang menjelma, baik buruk suka dan duka, semua itu akan dijalani dan dijumpai, baik di dunia maupun di akhirat.

Berdasarkan kutipan di atas, maka peranan orang tua dalam pendidikan anak, dalam pendidikan informal maupun dalam pendidikan formal, disini terlihat betapa penting kedudukan ilmu pengetahuan dalam kelangsungan kehidupan anak. Ini berarti dapat menyadarkan memori kolektif sebagaian pandangan orang 
tua terutama yang masih kurang, hingga merasa takut menyekolahkan anaknya, mudah-mudahan melalui kajian ini para orang tua semakin menyadari tugasnya terutama untuk menyekolahkan anaknya, sehingga berkat kesadarannya ini sekaligus membantu program pemerintah,yaitu mencerdaskan kehidupan bangsa.

- Pertama sekali si anak mendapat pendidikan adalah di rumah sebelum mereka memasuki bangku Sekolah Dasar (SD), materi apa yang diberikan oleh orang tua kepada anaknya, dan kapan harus menasehati anak dapat dilihat pada kutipan berikut :

Yan mungguing pakayun Ida, sang meraga sampun lwih, becik nuturin sentana, rikalane kari alit, masastra patut ajahin, dados dangan pacang nurut, yaning, dening ipun sampun mindra, meweh pacang mangajahin, dening ipun, kaliput manah byapara. (PS: Puh. Sinom, b.10).

Terjemahannya

Seperti halnya pikiran beliau, orang yang berpikir baik, sangat bagus menasehati/memberikan ajaran kepada si anak, pada saat masih kecil, ajarkan mereka bersastra, memang sangat mudah menurut, bila ia sudah remaja, sulit akan mengajari, sebab ia diliputi oleh pikiran yang egois.

Melihat kutipan di atas adalah sutau metode dalam mengajar anak-anak, seperti yang pernah dikemukakan oleh John Locke tentang teori Tabularasa, yang mana anak yang baru lahir bagaikan kertas putih, maka mau ditulisi apa, mau dijadikan apa anak itu tergantung dari pendidikan, memang mengajarkan anakanak harus mulai dari kanak-kanak, seperti pepatah orang Bali "masa kanakkanak bagaikan daun alang-alang muda" masih sedang tajam untuk menusuk, akan tetapi salah menusukan akan mengakibatkan kepatalan bagi si anak itu sendiri, sedangkan setelah tua dia akan semakin tumpul.

- Hakekat Ilmu Pengetahuan Untuk Kehidupan Manusia : Ilmu Pengethuan adalah harta kekayaan yang kekal dan abadi betapa pentingnya kedudukan ilmu pengetahuan itu untuk mempermudah dalam kehidupan umat manusia, seperti terdapat pada kutipan di bawah ini :

Punika awanan bwatang, sastrane jwa palajahin, sakeng kotamaning sastra, anggon ngrereh mas pipis, punika lwihing pikolih, sangsat kadi sang mapekayun, ring kalwihan kwikanan, mula saking sanghyang aji, rawuh ipun, awanan manggih kasadyan(PS: Puh. Sinom, b.28).

Terjemahan :

Itulah yang patut dicari, tentang sastra yang patut dipelajari, kebenaran dan kebaikan sastra, dipakai sebagai alat untuk mencari harta, sebab itu adalah keberhasilannya yang paling berhasil, bagaikan orang berpikir, tentang kebaikan dan kepintaran, semua itu berasal dari ilmu pengetahuan, kalau itu sudah dikuasai, maka kebahagiaan akan segera datang.

Berdasarkan kutipan di atas, nampaknya pendidikan itu sangat menentukan juga kelangsungan hidup manusia, keutamaan dari ilmu pengetahuan itu dapat dipakai untuk mencari harta kekayaan, ilmu pengetahuan membantu manusia mempermudah dalam memenuhi kebutuhan hidupnya. Dapat dirasakan ketika bangsa Indonesia pada jaman penjajahan, yang mana pada jaman itu rakyat 
Indonesia belum banyak yang mengenyam pendidikan, maka Bangsa Indonesia pada waktu itu lahir dan batin khusunya bagi pejuang bangsa yang hidup pada jaman itu mengalami berbagai keterbatasan. Ilmu pengetahuan menyebabkan orang menjadi bahagia itu pun kalau tidak salah digunakannya.

Aspek-aspek pendidikan dalam Geguritan Basur :aspek-aspek pendidikan dalam Geguritan Basur yang dapat disimak antara lain :

- Sistem pendidikan seumur hidup yang mana pada hakikatnya proses pendidikan dan proses belajar berlangsung seumur hidup, seperti apa yang diamanatkan pada kutipan berikut :

Eda ngaden awak bisa/depang anake ngadanin/geginane buka nyampat/anak sai tumbuh luwu/ilang luwu buke katah/yadin ririh/liu enu palajahin//(Bs: Puh. Ginada, b.18).

Terjemahan :

Jangan keburu membilang diri pintar/biarkan orang lain mengatakan/bagaikan orang yang selalu menyapu/tetapi tetap saja ada sampah/ hilang sampahnya tetapi debunya masih/ walau orang itu pintar/ tetapi masih banyak yang perlu dipelajari//

Sebait kutipan pupuh ginada di atas, sudah amat populer di masyarakat Bali, bukan saja bagi orang-orang tua, namun juga dikalangan anak-anak muda. Bila dikaji lebih dalam makna secara prinsip adalah semasih hidup, walaupun bagaimana pintarnya seseorang, ada saja yang masih belum mereka ketahui dan itu perlu mereka pelajari, kesemua ini sudah menjadi kodrat manusia yang ada di dunia serta jangan terburu merasa takabur dengan pengetahuan yang dimiliki. Hendaknya mengakui kelebihan orang lain, kutipan diatas menyiratkan juga tentang sistem demokrasi dengan memberikan kesempatan kepada orang lain untuk mengeluarkan pendapat, serta menghargai pendapat orang lain.

- Mendidik anak-anak untuk hidup hemat dan ini dituangkan dalam sistem tabungan atau celengan. Konsepsi ini telah dituangkan dalam Geguritan Basur yaitu tentang hidup hemat yang perlu ditanamkan pada anak didik sedini mungkin, seperti terlihat pada kutipan berikut.

Yan mangelah pipis patpat/dadua sepal apang ilid/yan dasa mangelah jinah/lalima sepal di bungbung/makelo ada antosang/anggen kancrik/ede goroh budag amah// (Bs:Puh. Ginada, b.13).

Terjemahannya :

Kalau mempunyai uang empat/yang dua itu disimpan/bila mempunyai uang sepuluh/yang lima itu disimpan/setelah lama pastilah jumlah uang itu akan banyak/pakailah itu untuk membeli keperluan hidup, selendang/jangan boros dan berfoya-foya//

Melihat kutipan di atas, berarti ide tentang sistem menabung yang diarahkan pada masa kanak-kanak telah ada terkandung dalam Geguritan Basur.Sekarang telah menjadi sistem menabung di sekolah, membiasakan anakanak, otomatis mengajarkan pada mereka itu supaya belajar hidup hemat, dan tidak boros, dan yang terpenting adalah melatih kedisiplinan mereka, kalau di sekolah Sekolah Dasar sistem menabung sudah berjalan dan dipungut oleh guru 
wali kelas, namun sejak ada satgas saber pungli semua sekolah tidak berani melakukan itu lagi. Sesungguhnya hakikat dasar tabungan ini adalah membangun karakter yang baik (hemat, tanggung jawab, mandiri, berpikir masa depan), namun pemerintah justru membabi buta mengklasifikasikan pungutan liar itu sendiri.Disarankan bahwa setengah dari uang yang itu harus disimpan, namun dalam menghadapi kemajuan teknologi dewasa ini, menuntut manusia kepada kebutuhan yang semakin kompleks, oleh sebab itu mungkin tidak selalu harus setengah yang disimpan, tetapi uang yang dimiliki itu tidaklah harus juga untuk dihabiskan sekaligus keseluruhannya dengan adanya tuntutan kebutuhan manusia itu.

- Belajar secara terus-menerus : memang sulit untuk menerapkan sistem belajar secara kontinu, sebab anak didik dewasa ini cenderung belajar hanya pada saat menghadapi ujian atau ulangan saja, ia hanya mengejar nilai yang tanpa disadari oleh kemampuan yang mereka miliki. Bagi orang Bali konsep belajar itu dikatakan sebagai cermin diri, sebab di dalam sastra banyak petuah-petuah yang berguna bagi hidup mereka, seperti pada kutipan berikut ini :

Eda meed mlajah sastra/sai-sai plajahin/anggon manyuluhin raga/ala ayune katepuk/ring sekala lan niskala/nging da banggi/wireh ngelah kawisesan//(Bs: Pupuh Ginada).

Terjemahannya :

Jangan bosen mempelajari ilmu pengetahuan/hendaknyalah sering-sering dipelajari/dipakai sebagai cermin dalam diri/sehingga baik-buruk kita sendiri kita ketahui/baik di dunia fana maupun di dunia akhirat/tetapi jangan mabuk/baru mempunyai kepandaian//

Melihat kutipan di atas, dapat dikatakan merupakan suatu metode belajar yang cukup baik, disarankan membiasakan diri untuk belajar secara terusmenerus, tiap hari walaupun sedikit tetapi sering, dibandingkan sekali belajar dengan banyak buku yang dibaca, malahan cara yang semacam itu akan membuat kelabakan dalam mengingatnya, sehingga apa dibaca tadi tak ada manfaatnya dan waktupun terbuang dengan percuma tanpa hasil.

Aspek Pendidikan Dalam Cerita Tantri: oleh karena cerita tantri merupakan teks prosa, maka pada kajian ini tak disertakan kutipan, sebab yang ditampilkan adalah amanat secara keseluruhan yang mengandung aspek pendidikan. Adapun dalam cerita tantri aspke-aspek pendidikan yang dapat disimak adalah sebagai berikut :

- Konsep teori Tabularasa: konsep ini maksudnya menyatakan bahwa, anak yang baru lahir seperti kertas putih. Mau dijadikan apa anak itu tergantung pada orang yang memberikan ajaran-ajaran kepada anak itu dan juga pada lingkungan yang bagaimana anak itu dididik, maka begitulah ia atau waktunya setelah mereka menjadi remaja. Konsep ini terdapat pada cerita Tantri episode "I Kedis Atat Satinut Lan Kakasihannya" (Si burung kakaktua menurut apa yang dikatakan temennya).Diceritakan ada dua ekor burung kakak tua yang satu dipelihara oleh pendeta dan satu lagi dipelihara oleh pemburu, yang dipelihara oleh pendeta mempunyai watak yang baik, sedangkan yang dipelihara oleh si pemburu mempunyai watak yang bengis. 
Jika dikaji dari kehidupan manusia, bahwa burung kakak tua merupakan simbol dari kehidupan manusia, terutama dari dunia anak-anak, watak seorang anak tergantung pada lingkungan, baik lingkungan keluarga sekolah maupun masyarakat.Bila salah mendidik, maka yang keluar adalah anak yang salah pula dalam hal ini anak yang mungkin tidak penurut atau bandel.Dengan ilustrasi di atas, diharapkan kepada pendidik, khususnya yang ikut menentukan perkembangan watak anak didik supaya betul-betul mendidiknya dengan kehalusan budi pekerti, ketrampilan, dan yang terpenting jangan coba untuk menggunakan kekerasan apapun bentuknya.

Profesi guru yang dipakai sebagai slogan "patut di gugu dan ditiru" hendaknya benar-benar diperhatikan dan dijalankan sebagai mana mestinya, dan ini merupakan suatu keterkaitan yang tak mungkin dapat dilepaskan antara anak didik dan gurunya, sebab bagaimanapun tingkah laku yang ada pada anak didik itu merupakan cermin dari yang mendidiknya.

- Nilai-nilai ini tercermin pada cerita Tantri Episode Prabhu Angling Dharma, yang mengisahkan tentang seorang raja yang memahami segala bahasa. Tat kala tidur dengan istrinya melihat cecak yang sedang berkasih-kasih, oleh karena beliau mengetahui bahasa binatang, maka beliau tersenyum mendengar pembicaraan si cecak itu, sang istri menjadi tersinggung dan cemburu, akhirnya mereka berdua sepakat untuk melakukan "masatya". Masatya adalah sebuah istilah yang mengacu pada sebuah aktivitas uji kesetiaan terhadap suami melalui membunuh diri dengan jalan terjun ke dalam api suci. Warna dkk. Kamus Bali - Indonesia. Angling Dharma batal untuk menceburkan diri dalam api, gara-gara mendengar percakapan kambing betina dan jantan yang saling sindir tentang kesetiaan seorang suami dan istri. Melalui ilustrasi itu, dapat dihubungkan dengan pendidikan yang luas, diharapkan tidak hanya tahu satu bahasa, tetapi lebih dari itu, namun apabila mampu menempatkan akan jelas kelihatan manfaat dari pengetahuan itu. Nilai-nilai didaktik pada cerita tantri pada prinsipnya adalah pendidikan moral atau budi pekerti dengan dasar akal (naya) yang sehat.

Aspek pendidikan Dalam Posya Cerita Bhagawan Dhomya: aspek-aspek pendidikan yang terdapat dalamPosya Cerita Bhagawan Dhomya adalah sebagai berikut :

- Adanya penekanan pada kualitas dan kseungguhan dalam melahirkan lulusan yang profesional). Nilai ini terermin dimana Bhagawan Dhomya yang mempunyai tiga orang murid masing-masing bernama Sang Arunika mengambil jurusan pertanian, Sang Utamanyu mengambil jurusan Tata Bhoga), dan Sang Weda mengambil jurusan Agama.

Sistem Pendidikannya adalah sistem pendidikan asrama, ketiga muridnya itu diuji (diberi pelajaran) dengan sangat ketat sesuai dengan bidangnya masingmasing dari tahap perencanaan sampai tahap akhir.Ujian yang diberikan berupa ujian berupa ujian fisik dan mental, sehingga diharapkan setelah memasuki tahap belajar, anak didik telah siap mental dan fisik, uji coba semacam ini diperlukan untuk mengukur kesungguhan dari pada siswa dalam menuntut ilmu.

- Tanggung Jawab Guru dan Murid : tanggung jawab sebagai seorang guru, yang sering di istilahkan dengan "pahlawan tanpa tanda jasa" itu memang amat 
berat. Di samping itu kata guru memang berarti sangat berat. Guru harus mampu bertanggung jawab terhadap tingkah laku si anak didik. Menjadi guru memang gampang, tetapi mampukah guru itu sebagai pendidik yang baik, pertanyaan semacam itu tak perlu dijawab sekarang, sebab guru bukan satusatunya yang menentukan keberhasilan anak didik, karena masih ada komponen yang lain. Seperti halnya Bhagawan Dhomya merupakan sosok guru yang bertanggung jawab, beliau mampu menguji dengan ketat dan mampu memberi jalan keluar (bahkan mampu menghidupkan muridnya yang mati dalam menempuh ujian), dalam memberikan pelajaran beliau tidak memilih. Melalui ide ini diharapkan para pendidik dalam menempa anak didik tidak setengah-setengah dan jangan pilih kasih dan harus merata. Sedangkan tanggung jawab sebagai seorang murid, mempunyai kewajiban seperti belajar dengan baik, patuh terhadap peraturan sekolah, hormat dan setia pada guru, sungguh-sungguh bersekolah sampai tamat, mempunyai pergaulan yang banyak terutama sesama teman sekolah, serta mampu menjaga nama baik pribadi dan sekolah.

6. Relevansi Nilai-nilai pendidikan yang termuat dalam sastra Bali klasik dalam rangka pengembangan karakter generasi muda saat ini.

Modernisasi Bali bersifat transformasi spiral yang mengadopsi modernisasi dalam tradisi menuju bentuk baru, namun nilainya masih tetap ajeg.Keajegan nilai ini yang memungkinkan berkembangnya keselarasan hidup masyarakat Bali, meskipun mengalami terpaan modernisasi bahkan globalisasi dewasa ini.Orang Bali membaurkan gagasan baru dan asing ke dalam bentuk tradisional. Ini memungkinkan penduduk tetap menciptakan gaya baru, untuk terus memasukkan kehidupan baru ke dalam budaya mereka, dan pada saat yang sama mereka tidak pernah kehilangan ciri Balinya (Covarrubias,1937:225). Kalau ingin melihat relevansi nilai-nilai pendidikan yang termuat dalam sastra Bali Klasik dalam upaya pengembangan karaktergenerasi muda dewasa ini dapat dikatakan sebagai berikut :

- Nilai ialahgagasan yang menyatakan bahwa orang tua yang tidak menyekolahkan anaknya adalah orang tua yang keliru. Hal ini relevan sekali dengan sistem pendidikan yang telah diprogramkan oleh pemerintah, pada jaman modern wajib belajar 12 tahun. Kemudian ide perhatian terhadap anak juga sangat relevan, yang mana bahkan sekarang telah ada hari anak-anak sedunia, yang mengandung makna pula orang tua harus lebih mencurahkan perhatiannya kepada anak-anaknya sebagai penerus cita-cita perjuangan bangsa.

- Konsep pendidikan seumur hidup, bagi orang Bali jauh sebelumnya telah ada ide atau gagasan yang memandang pendidikan berlangsung seumur hidup, akan tetapi secara teoretis tidak diungkapkan dengan jelas, masih perlu dikupas secara mendalam. Ide ini bila dikaitkan dengan upaya pembaharuan pendidikan dan pengajaran dewasa ini memang amat relevan. Jaman sekarang untuk memasuki bangku sekolah tidak perlu memandang usia, orang yang sudah tuapun bisa memasuki jalur formal seperti ada UPER SMP, UPER SMA (baca: Kejar Paket A-C) bahkan sampai pada perguruan tinggi, banyak orang yang sudah tua sekolah lagi. 
Jaman sekarang adalah abad informasi, siapa yang terlambat ia akan terbelakang, oleh sebab itu diperlukan belajar terus dalam berbagai desiplin ilmu untuk mengejar ketinggalan.

- Konsep yang membiasakan anak- anak untuk menabung juga amat relevan dengan sistem pengajaran terutama di Sekolah Dasar, kebiasaan ini telah berlangsung lama, dan sampai pada saat ini masih berlangsung, ide ini mendasari adanya konsep hidup hemat dan pola hidup sederhana. Masalahnya sejak satgas saber pungli dibentuk sekolah tidak lagi berani melakukan itu, sungguh sangat disayayangkan spirit pembangunan karakter diaduk oleh sebuah persoalan yang tak berujung pangkal.

- Konsep pendidikan akal yaitu konsep semacam ini sudah makin tipis dapat dilaksanakan, sebab berdasarkan penelitian 70\% anak-anak menggunakan sistem hapalan, sehingga daya nalarnya makin mandul, sebab sistem hapalan itu sifatnya sementara, sedangkan logika (nalar) bersifat fundamental.

- Tentang peranan guru atau tanggung jawab guru dan murid dalam pendidikan, baru-baru ini ada kasus perkelahian pelajar, terus siapa yang bertanggung jawab atas semua perlu direnungkan oleh komponen dasar yang menentukan hal itu tidak hanya orang tua dan guru namun seluruh komponen masyarakat. Sebagai guru tetap memegang tanggung jawab terhadap anak didik, dilain pihak peranan orang tua untuk mengasuh anak di rumah perlu juga, sehingga ada keterkaitan antara peranan guru di sekolah dengan orang tua di rumah, begitupula siswa itu harus turut apa pesan dan yang pernah diajarkan oleh orang tua di rumah dan guru disekolah hendaknya mendapatkan perhatian yang seksama untuk menghindari hal-hal yang tidak diinginkan bersama.

\section{PENUTUP}

Berdasarkan uraian di atas, maka dapat ditarik suatu kesimpulan sebagai berikut : Telah banyak peneliti-peneliti putra daerah yang telah berbicara tentang kesusastraan Bali, yang menyatakan bahwa sastra Bali sangat penting untuk diteliti, karena di dalamnya terkandung nilai-nilai yang berguna bagi kehidupan. Dalampenelitian ini dibahas empat buah naskah seperti :Geguritan Putra Sasana, Geguritan Basur, Cerita Tantri, dan Cerita Bhagawan Dhomya. Salah satu yang dikaji dari keempat cerita tersebut adalah unsur nilai didaktiknya.

Terjalinnya transformasi nilai-nilai didaktik yang terkandung dalam sastra klasik dan diteruskan dalam sistem pendidikan anak dalam kehidupan masyarakat Bali, walaupun tidak persis sama wujudnya seperti semula, tetapi telah berkembang sesuai dengan kemajuan jaman, seperti ide untuk menabung, pendidikan usia dini, pendidikan seumur hidup, dan sebagainya.Aspek-aspek pendidikan yang dapat disimak dalam sastra Bali klasik meliputi: tanggung jawab orang tua dalam proses pendidikan, pendidikan nonformal, hakikat ilmu pengetahuan, pendidikan seumur hidup, metode belajar, pendidikan akhlak dan akal, tanggung jawab guru dan murid.Semua nilai didaktik ini mempunyai relevansi dalam upaya pengembangan karakter generasi muda dewasa ini, dalam 
artian tidak ada yang terlalu menyimpang, hanya saja metode pengajaran berbeda yang dipandang perlu diperbaharui.

\section{DAFTAR PUSTAKA}

Agastia, I.B.G. 1980. Geguritan Sebuah Bentuk Karya Sastra. Paper Sarasehan Sastra Bali, Pesta Kesenian Bali ke 2 Art Cantre Denpasar.

Agastia, I.B.G. 1984. "Cerita Tanuri Dalam Kasusastraan Bali” Widya Pustaka, Fakultas Sastra Unud.

Astra, I Gede Semadi.2004.“ Revitalisasi Kearifan Lokal Dalam Upaya

Memperkokoh Jati Diri Bangsa”. Dalam Politik dan Identitas

Etnik.Editor I Wayan Ardika dan I Nyoman Darmaputra. Denpasar: FS

Unud dan Bali Mangsi Press.

Atmazaki.1990. Ilmu Sastra.Teori dan Terapan. Bandung: Angkasa

Ayatrohaedi.1986. Editor.Kepribadian Budaya Bangsa. Jakarta: Pustaka Jaya.

Bagus, I Gusti Ngurah.1968.Arti Dongeng Bali Dalam Pendidikan.Direktorat Bahasa dan Kesusastraan, Direktorat Djendral Kebudayaan Depdikbud Cabang Singaraja.

Bagus, I Gusti Ngurah.1989.Nilai Dongeng, Pendidikan, dan Proses Pembudayaanya. Denpasar: Pustaka Siddhanta.

Damono, Sapardi Djoko. 1978.Sosiologi Sastra Sebuha Pengantar Ringkas. Jakarta:Pusat Pembinaan dan Pengembangan Bahasa Depdikbud.

Esten, Mursal.1990. Kesusastraan.Pengantar Teori dan Sejarah. Bandung. Angkasa

Gie, The Liang. 1983.Garis-Garis Besar Estetika (Filsafat Keindahan).Yogyakarta: Penerbit Supersukses.

Idris Zahara. 1988.Dasar-Dasar Kependidikan. Bandung: Angkasa.

K.M. Saini.1989.Protes Sosial Dalam Sastra. Bandung: Angkasa.

Mantra, Ida Bagus.1996.Landasan Kebudayaan Bali. Denpasar: Yayasan Dharma Sastra.

Poespowardoyo, Soerjono.1986.Masalah Perubahan Nilai dan Strategi

Kebudayaan. Dalam J.A. Denny (ed).Jakarta:Transformasi Masyarakat

Indonesia.

Poerbatjaraka, R.Ng.1933, NitiçastraOud Javaansche tekst met Vertaling. Bandung: A.C. NIX.

Robson, S.O.1978. Pengkajian Sastra Nasional dan Sastra-Sastra Klasik Indonesia.Bahasa dan Sastra, Th. IV.No. 6.

Sulastin-Sutrisno.1981. Relevansi Studi Filologi.Pidato Pengukuhan Guru Besar dalam Bidang Ilmu Filologi Fakultas Sastra Universitas Gajah Mada.

Teeuw, A. 1988. Sastra dan Ilmu Sastra. Pengantar Teori Sastra. Jakarta: Pustaka Jaya.

Teeuw, A.1991. Membaca dan Menilai Sastra. Jakarta: Gramedia.

Tim Penyusun.2007. Kamus Istilah Agama Hindu. Denpasar: Pemerintah Kabupaten Bangli.

Toffler, Alvin,1990. The Third Wave.Gelombang Ketiga. Jakarta: Pantja Simpati. 
Trijono, Lambang,1996. “Globalisasi Modernitas dan Krisis Negara Bangsa; Tantangan Integrasi Nasional dalam Konteks Global” dalam Analisis CSIS. Tahun XXV No.2 Maret-April. Jakarta: CSIS.

Warna dkk.1991.Kamus Bali Indonesia. Denpasar: Dinas Pendidikan Dasar Provinsi Bali.

Yudibrata, Karna. 1982. "Peranan Seni Dalam Membina Masyarakat Akademik di IIngkungan Pendidikan Guru". Dalam Analisis Kebudayaan No. 2.Jakarta: Depdikbud.

Zoetmulder, P.J.1995. Kamus Jawa Kuna- Indonesia.Bekerjasama dengan S.O Robson.Penerjemah Darusuprapta dan Sumarti Suprayitna. Jakarta: PT. Gramedia Pustaka Utama.

Sumber Pustaka

Kitab Adi Parwa Jawa Kuna-Arti bahasa Indonesia. Siman Widyatmanta.

Lontar Geguritan Putra Sasana Koleksi Pusdok Provinsi Bali

Lontar Geguritan Basur Koleksi Pusdok Provinsi Bali

Satua Katuturan Ni Dyah Tantri buku karya I Made Pasek. 